\title{
Antileishmanial Activity of Selected Turkish Medicinal Plants
}

\begin{abstract}
Ahmet Ozbilgin ${ }^{1}$, Cenk Durmuskahya ${ }^{2}$, Husniye Kayalar ${ }^{3 *}$, Hatice Ertabaklar ${ }^{4}$, Cumhur Gunduz ${ }^{5}$, Ipek Ostan Ural ${ }^{6}$, Fadile Zeyrek ${ }^{7}$, Ozgur Kurt ${ }^{8}$, Ibrahim Cavus $^{1}$, Cuneyt Balcioglu', Seray Ozensoy Toz ${ }^{9}$ and Yusuf Ozbel ${ }^{9}$

${ }^{1}$ Department of Parasitology, Faculty of Medicine, Celal Bayar University, Manisa, ${ }^{2}$ Izmir Katip Celebi University, Faculty of Forestry, Department of Forest Engineering, Balatcik, ${ }^{3}$ Department of Pharmacognosy, Faculty of Pharmacy, Ege University, Izmir, ${ }^{4}$ Department of Parasitology, Faculty of Medicine, Adnan Menderes University, Aydın, ${ }^{5}$ Department of Medical Biology, Faculty of Medicine, Ege University, Izmir, ${ }^{6}$ Vocational School of Health Services, Celal Bayar University, Manisa, ${ }^{7}$ Department of Microbiology, Faculty of Medicine, Harran University, Sanlıurfa, ${ }^{8}$ Department of Microbiology, Faculty of Medicine, Acıbadem University, Istanbul, ${ }^{9}$ Department of Parasitology, Faculty of Medicine, Ege University, Izmir, Turkey
\end{abstract}

*For correspondence: Email: husniyekayalar@gmail.com; Tel: +90-232-3112549; Fax: +90-232-3885258

\begin{abstract}
Purpose: To determine the in vitro and in vivo anti-leishmanial activities of extracts obtained from Centaurea calolepis, Phlomis lycia, Eryngium thorifolium, Origanum sipyleum and Galium incanum ssp. centrale.

Methods: To estimate the cytotoxicity of plant extracts, WST-1 assay was used. Parasite inhibition in the presence of plant extracts $(25-500 \mu \mathrm{g} / \mathrm{ml}$ ) in comparision with control group and reference group (glucantime, $25 \mu \mathrm{g} / \mathrm{ml}$ ) at 12 - $72 \mathrm{~h}$ were determined in vitro on L. tropica promastigotes. The in vivo leishmanicidal activity of the extracts was evaluated against $L$. tropica-infected mice with glucantime as reference drug.

Results: The chloroform extract of Galium incanum ssp. centrale showed the highest cytotoxicity with $I C_{50}$ value of $0.0316 \pm 0.005 \mu \mathrm{g} / \mathrm{ml}$. In vitro parasite inhibition by the plant extracts ranged between 16.7 $\pm 0.01 \%$ and $100 \pm 0.00 \%$ at $25 \mu \mathrm{g} / \mathrm{ml}$ concentration. The methanol extract of Eryngium thorifolium possessed the highest activity on promastigotes of L. tropica with $100 \%$ inhibition at $25 \mu \mathrm{g} / \mathrm{ml}$. The water and chloroform extracts of $C$. calolepis and water and methanol extracts of $E$. thorifolium at a dose of $100 \mathrm{mg} / \mathrm{kg}$ reduced parasitaemia in L. tropica infected mice.

Conclusion: Parasite viability results suggest that the methanol extract of Eryngium thorifolium, regarded as non-cytotoxic, is a promising candidate drug for treating L. tropica infection.
\end{abstract}

Keywords: Leishmaniasis, Leishmania tropica, Eryngium thorifolium, Promastigote, WI-38 Human fibroblasts

Tropical Journal of Pharmaceutical Research is indexed by Science Citation Index (SciSearch), Scopus, International Pharmaceutical Abstract, Chemical Abstracts, Embase, Index Copernicus, EBSCO, African Index Medicus, JournalSeek, Journal Citation Reports/Science Edition, Directory of Open Access Journals (DOAJ), African Journal Online, Bioline International, Open-J-Gate and Pharmacy Abstracts

\section{INTRODUCTION}

Leishmaniasis is a vector-borne disease affecting 400 million people around the world. This public health problem is endemic in 88 countries. After malaria, leishmaniasis is the most important parasitic disease caused by protozoan parasite species from Leishmania genus [1]. Sodium stilbogluconate and meglumine antimonite are the most favourable leishmanicidal agents. These pharmaceutical agents administered by injection usually cause pain at the site of injection. In addition to stiff joints and gastrointestinal disorders, they have also been 
known to cause cardiotoxicity and severe hepatic and renal insufficiencies [2].

Natural herbal products have been used in the treatment of infectious disease for many years. The World Health Organisation (WHO) emphasized that plants used in traditional medicine should primarily be investigated against leishmaniasis [1]. All over the world, researchers started on this issue and successful results were achieved [3-5].

With this knowledge and as part of our outgoing studies on anti-parasitic activities of Turkish medicinal plants [6-8], in the present work, antileishmanial efficacies of extracts prepared from Centaurea calolepis Boiss. Phlomis lycia D. Don., Eryngium thorifolium Boiss., Origanum sipyleum L., Galium incanum ssp. centrale Ehrend. were examined on Leishmania tropica promastigote and amastigote forms. In addition to preliminary phytochemical screening analysis, cytotoxic activities of each plant extract were also determined by WST-1 cell proliferation assay.

\section{EXPERIMENTAL}

\section{Plant material}

The aerial parts of Centaurea calolepis Boiss., Phlomis lycia, Eryngium thorifolium, Origanum sipyleum, Galium incanum ssp. centrale were collected from various localities in Turkey. The plant species were identified by Dr. Cenk
Durmuskahya (Izmir Katip Celebi University, Faculty of Forestry, Department of Forest Engineering, Balatcik, İzmir Turkey) and voucher specimens were deposited in Department of Pharmacognosy, Faculty of Pharmacy, Ege University, Izmir, Turkey (The collection areas for the plants, voucher numbers, extracts and their antimicrobial or antiprotozoal effects as well as the phytochemical profile of the plants are listed in Table 1).

\section{Preparation of plant extracts}

The plant materials were ground into a fine powder after air-drying. The methanol and chloroform extracts were prepared by maceration under stirring for $48 \mathrm{~h}$ at $24{ }^{\circ} \mathrm{C}$ where the solvent/plant material ratio was $15: 1$. The water extracts were prepared by $2 \%$ infusion and all the extraction solvents were filtered through Whatman filter paper no.1. The filtrates were evaporated to dryness under reduced pressure in a rotary evaporator at $40{ }^{\circ} \mathrm{C}$. The residues were lyophylised and stored in screw capped vials at $20{ }^{\circ} \mathrm{C}$ until analysed.

\section{Phytochemical analysis of plant extracts}

Phytochemical screening tests for plant secondary metabolites such as tannins, terpenoids, saponins, flavonoids and alkaloids were conducted on the plant extracts as described by Trease and Evans [9] and Harborne [10].

Table 1: Medicinal plants investigated for their anti-leishmanial and cytotoxic activities

\begin{tabular}{|c|c|c|c|c|}
\hline $\begin{array}{l}\text { Plant name/ Familyl } \\
\text { Voucher number }\end{array}$ & Collection area & Extract & $\begin{array}{l}\text { Secondary metabolites } \\
\text { antimicrobial/antiprotozal } \\
\text { activity }\end{array}$ & Reference \\
\hline $\begin{array}{l}\text { Centaurea calolepis } \\
\text { Boiss./ Asteraceae/ } 1447\end{array}$ & $\begin{array}{l}\text { Antalya, Elmalı, } \\
1100 \mathrm{~m}\end{array}$ & water, chloroform & $\begin{array}{l}\text { Flavonoids, sesquiterpenes; } \\
\text { antimicrobial, antiprotozoal }\end{array}$ & {$[11,12]$} \\
\hline $\begin{array}{l}\text { Eryngium thorifolium } \\
\text { Boiss./ Umbellifera/ } 1446\end{array}$ & $\begin{array}{l}\text { Muğla, Koycegiz, } \\
\text { Kandil Mountain, } \\
600 \text { m }\end{array}$ & water, methanol & $\begin{array}{l}\text { Flavonoids, saponins; } \\
\text { Antiprotozoal }\end{array}$ & [13-15] \\
\hline $\begin{array}{l}\text { Origanum sipyleum L./ } \\
\text { Labiatae /1445 }\end{array}$ & $\begin{array}{l}\text { Manisa, Spil } \\
\text { Mountain, } 1050 \mathrm{~m}\end{array}$ & water, methanol & $\begin{array}{l}\text { Triterpenes (ursolic acid, } \\
\text { oleanolic acid); antimicrobial, } \\
\text { antiprotozoal }\end{array}$ & {$[13,16,17]$} \\
\hline $\begin{array}{l}\text { Galium incanum SM. } \\
\text { subsp. centrale } \\
\text { Ehrend./Rubiaceae/ } \\
1432\end{array}$ & $\begin{array}{l}\text { Izmir, Bozdağ, } \\
1500 \mathrm{~m}\end{array}$ & water, chloroform & $\begin{array}{l}\text { Flavonoids, anthracenes, } \\
\text { iridoids; antiprotozoal }\end{array}$ & {$[18,19]$} \\
\hline $\begin{array}{l}\text { Phlomis lycia D. Don/ } \\
\text { Labiatae/ } 1448\end{array}$ & $\begin{array}{l}\text { Antalya, Korkuteli, } \\
550 \mathrm{~m}\end{array}$ & water, chloroform & $\begin{array}{l}\text { Iridoids, flavonoids, } \\
\text { diterpenes; antimicrobial }\end{array}$ & {$[20,21]$} \\
\hline
\end{tabular}




\section{Determination of cytotoxic effect $\left(\mathrm{IC}_{50}\right)$ of plant extracts}

Plant extracts in a concentration range of 0.001 $100 \mu \mathrm{g} / \mathrm{ml}$ were prepared by dilution with water and $\mathrm{IC}_{50}$ values determined by using "xCELLigence Real-Time Cell Analyzer" in $96 \mathrm{~h}$. A total of $2 \times 10^{6} / \mathrm{ml} \mathrm{WI-38} \mathrm{human} \mathrm{fibroblast} \mathrm{cells}$ were distributed for each cell line in the plates having 96 gold-coated wells, including the control group without plant extract. Each assessment was run in triplicate. $\mathrm{IC}_{50}$ values of the plant extracts in each cell line were determined using a calorimeter with WST-1 (4-[3-(4-iodophenyl)-2(4-nitrophenyl)-2H-5-tetrazolio]-1,3-benzene disulfonate) test. Following the addition of WST1 , all extracts were kept for $4 \mathrm{~h}$ inside an incubator with $5 \% \mathrm{CO}_{2}$ and $95 \%$ humidity at 37 ${ }^{\circ} \mathrm{C}$. The yellow-orange colored product, stable soluble formazan, was quantified at $450 \mathrm{~nm}$ and $620 \mathrm{~nm}$ reference interval using a Multiscan FC Thermo Scientific microplate reader [22].

\section{Preparation of Leishmania tropica isolates}

Following clinical diagnosis by dermatologist at Harran University Hospital, Urfa, L. tropica was isolated from the patients with cutaneous leishmaniasis infection in Sanlıurfa province which is an endemic area for this infection. Skin lesions of the patients were cleansed with $70 \%$ ethanol before sample aspiration. A 26-gauge needle with syringe containing $0.1-0.2 \mathrm{ml}$ of sterile saline was then inserted intradermally into the outer border of the lesion. The syringe was rotated and the tissue fluids were gently aspirated and partly smeared on three slides [23]. These preparations were stained with Giemsa and examined under alight microscope.

The remaining aspiration material was inoculated immediately in Nicolle-Novy-McNeal (NNN) culture medium. The culture tubes were kept in an incubator at $25{ }^{\circ} \mathrm{C}$ for 7 days. L. tropica promastigote observed during microscopy were transferred to flasks containing RPMI-1640 medium (Biochrom AG), $10 \%$ fetal calf serum (FCS), $200 \mathrm{U} / \mathrm{ml}$ of penicillin and $0.2 \mathrm{mg} / \mathrm{ml}$ of streptomycin and incubated at $25{ }^{\circ} \mathrm{C}$ for mass cultivation. Promastigotes were collected by centrifugation at $1500 \mathrm{rpm}$ at $4{ }^{\circ} \mathrm{C}$ for $10 \mathrm{~min}$ and washed with sterile saline before analysis. Leishmania promastigotes were kept in liquid nitrogen at $-196^{\circ} \mathrm{C}$ until the analysis. The identification of Leishmania species and isoenzyme analysis were conducted according to the procedure of the World Health Organisation Leishmania Reference Center [1].

\section{In vitro antileishmanial assay}

Concentrations of plant extracts $(25,50,125$, 250 and $500 \mu \mathrm{g} / \mathrm{ml}$ ) were prepared for in vitro experiments. The extracts were dissolved in dimethyl sulfoxide (DMSO) and diluted in RPMI medium containing $10 \%$ FCS. The final volume was adjusted to $2 \mathrm{ml}$ with RPMI medium for each well of a 24-well microplate. In all experiments, in order not to affect parasite growth rate, mobility or morphology, the final concentration of DMSO was not higher than $0.5 \%(\mathrm{v} / \mathrm{v})$ [24]. After haemocytometer counting, promastigotes were suspended to yield $1 \times 10^{6} \mathrm{cell} / \mathrm{s} / \mathrm{ml}$ in each well. As a reference drug, a pentavalent antimonial compound, glucantime was prepared in sterile DMSO. The highest concentration of DMSO and RPMI medium were also used for untreated groups. Microplates were incubated at $25{ }^{\circ} \mathrm{C}$. The number of parasites were counted with a haemocytometer (Thoma slide) under a light microscope in $12-72$ h. $[6,25,26]$. All the in vitro experiments were run in triplicate and the results were expressed as mean percent inhibition in parasite number.

\section{In vivo antileishmanial assay}

\section{Animals and experimental infection}

Female Balb-C mice (20 - 25 g, 5 - 7 weeks old) were obtained from Ege University Experimental Animals Center. The mice were maintained on standard pelleted diet and water ad libitum. The study was approved by the Animal Ethics Comittee, Ege University. Promastigotes were cultured in RPMI-1640 medium supplemented with $10 \%$ FCS and collected on the 14th day of the culture. Ten milliliters of the culture fluid was centrifuged and a final dilution of $1 \times 10^{8}$ promastigotes $/ \mathrm{ml}$ was prepared. The promastigote solution $(15 \mu \mathrm{ll})$ was injected subcutaneously into the right hind footpads of the mice [6]. The development of the lesion was measured weekly with a dial micrometer during the course of infection. The infection was well established and lesions were obvious.

\section{Drug administration}

The mice were divided into 13 groups $(n=7)$. Treatment trials were initiated 30 days after the establishment of infection. Ten extracts prepared from the plant materials (water and chloroform extracts of Centaurea calolepis, Galium incanum ssp. centrale, Phlomis lycia and water and methanol extracts of Eryngium thorifolium and Origanum sipyleum) were administered at a dose

Trop J Pharm Res, December 2014; 13(12): 2049 
of $100 \mathrm{mg} / \mathrm{kg}$. Glucantime was used as a reference drug at a dose of $28 \mathrm{mg} / \mathrm{kg}$ [6]. As a negative control, sterile saline solution was administered to mouse in the untreated group. A placebo group was included in the study. All injections were administered intralesionally at 15 $\mu \mathrm{l}$, five times with 3 -day intervals. The size of developing lesions on the footpads of the mice was measured with a dial micrometer weekly during the course of infection and expressed as the differences in size between the infected and uninfected footpads. The parasite vitality was also investigated in the established infection. Needle aspiration samples were taken from infected lesions before and after the treatment. The samples were stained with Giemsa and examined under oil immersion with a light microscope to detect amastigotes. On the 60th day of infection, $50 \mathrm{mg}$ tissue samples were taken from the edges of the lesions for biopsy. They were smeared on the slides, stained with Giemsa and examined on the microscope to search for amastigote form of $L$. tropica. Some part of biopsy samples were inoculated in NNN medium for investigation of the live promastigotes. Touch slides were also prepared from the samples for investigation of the amastigotes by PCR after DNA isolation.

\section{Statistical analysis}

The results of assessments were analysed using Student's t-test with Windows SPSS Version 15.0. $P>0.05$ was taken as statistically significant.

\section{RESULTS}

\section{Phytochemical analysis}

The extraction yields in percentages and the results of preliminary phytochemical analysis of screened plants were demonstrated in Table 2. All the extracts except for water extracts of $C$. calolepis and $P$. lycia, gave positive results for terpenoids. Water extract of $C$. calolepis were positive for flavonoids, tannins and anthracenes. The chloroform extract of $P$. lycia possessed terpenoids and flavonoids. Water and methanol extracts of $O$. sipyleum and $E$. thorifolium were positive for terpenoids, flavonoids and tannins. Anthracenes were present in the water extract of E. thorifolium.

\section{Cytotoxicity of plant extracts}

The $\quad I_{50}$ values of plant extracts were summarised in Table 3. The chloroform extract of Galium incanum ssp. centrale showed the highest cytotoxic activity at a concentration of $0.03615 \pm 0.005 \mu \mathrm{g} / \mathrm{ml}$. Chloroform extract of Centaurea calolepis possessed greater cytotoxicity against WI-38 cell lines than its water extract with $\mathrm{IC}_{50}$ values of $12.6 \pm 0.611$ and $141.21 \pm 0.168 \mu \mathrm{g} / \mathrm{ml}$ respectively. Water and chloroform extracts of Phlomis lycia showed activity with an $\mathrm{IC}_{50}$ value of $139.19 \pm 0.185$ and $748.58 \pm 0.311 \mu \mathrm{g} / \mathrm{ml}$ respectively. Meanwhile, water and methanol extracts of Eryngium thorifolium and water extract of Galium incanum ssp. centrale had proliferative activities on cell lines.

Table 2: Extraction yield and preliminary phytochemical analysis of plant extracts

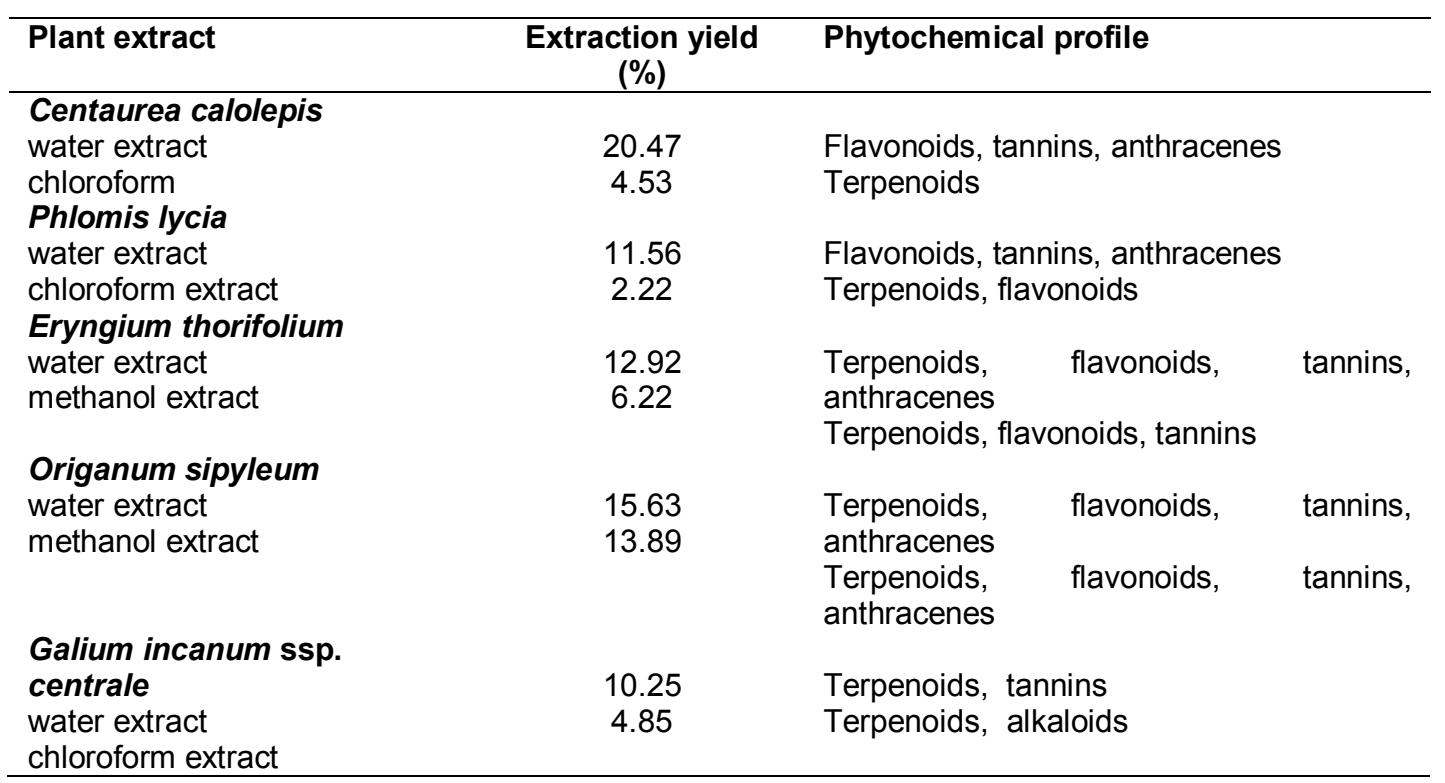


Table 3: $\mathrm{IC}_{50}$ values for plant extracts tested against WI-38 cell lines

\begin{tabular}{|c|c|}
\hline Plant extract & $\mathrm{IC}_{50}(\mu \mathrm{g} / \mathrm{ml})^{*}$ \\
\hline $\begin{array}{l}\text { Centaurea calolepis } \\
\text { water extract } \\
\text { chloroform extract }\end{array}$ & $\begin{array}{l}141.21 \pm 0.168 \\
12.6 \pm 0.612\end{array}$ \\
\hline $\begin{array}{l}\text { Phlomis lycia } \\
\text { water extract } \\
\text { chloroform extract }\end{array}$ & $\begin{array}{l}139.19 \pm 0.185 \\
748.58 \pm 0.311\end{array}$ \\
\hline $\begin{array}{l}\text { Eryngium thorifolium } \\
\text { water extract } \\
\text { methanol extract }\end{array}$ & $\begin{array}{l}\text { proliferative } \\
\text { proliferative }\end{array}$ \\
\hline $\begin{array}{l}\text { Origanum sipyleum } \\
\text { water extract } \\
\text { methanol extract }\end{array}$ & $\begin{array}{l}1588.3 \pm 1.371 \\
270.47 \pm 0.503\end{array}$ \\
\hline $\begin{array}{l}\text { Galium incanum ssp. } \\
\text { Centrale } \\
\text { water extract } \\
\text { chloroform extract }\end{array}$ & $\begin{array}{l}\text { proliferative } \\
0.03615 \pm 0.005\end{array}$ \\
\hline
\end{tabular}

\section{In vitro anti-leishmanial activity}

All the plant extracts showed inhibitory activity ranging between 16.70 and $100 \%$ at twelfth hour analysis at $25 \mu \mathrm{g} / \mathrm{ml}$ concentrations (Table 4). Results showed that all the extracts at $500 \mu \mathrm{g} / \mathrm{ml}$ concentration exhibited parasite inhibiton percentages ranging between $61.7 \%$ and $100 \%$ at twelfth hour. The chloroform extract of Centaurea calolepis, Phlomis lycia and Galium incanum ssp. centrale were found to have higher activity than the water extracts of mentioned plants. As shown in Table 4, at twelfth hour, water extract of Centaurea calolepis reached $99.2 \%$ parasite inhibition at a concentration of $500 \mu \mathrm{g} / \mathrm{ml}$ whereas the chloroform extract showed $100 \%$ inhibition at $50 \mu \mathrm{g} / \mathrm{ml}$ concentration at 24th hour. Water extract (500 $\mu \mathrm{g} / \mathrm{ml}$ ) of $P$. lycia had $98.4 \%$ inhibition at twelfth hour, whereas $99.4 \%$ parasite inhibition was observed for the chloroform extract of $P$. lycia at $25 \mu \mathrm{g} / \mathrm{ml}$. In comparison with the untreated group, except for twelfth hour analysis results of water extract of Galium incanum ssp. centrale and methanol extract of Origanum siypleum $(p>$ 0.05), all the extracts showed significant differences $(p<0.01)$. Methanol extract of Eryngium thorifolium with $100 \%$ parasite inhibition at $25 \mu \mathrm{g} / \mathrm{ml}$ concentration possessed highest activity on promastigotes of $L$. tropica.

\section{In vivo antileishmanial activity}

In the in vivo anti-leishmanial activity assays of plant extracts, the average measurement of the lesions on the footpads of mice in infected but untreated group reached $3.32 \pm 0.01 \mathrm{~mm}$ (Figure 1) whereas the reference glucantime group had an average of $1.71 \pm 0.01 \mathrm{~mm}$ lesion size at the end of 8th week. All the extracts, except for water and chloroform extracts of $G$. incanum and chloroform extract of $P$. lycia, significantly decreased the lesion sizes of mice in treatment groups (Table 5). At the end of the 8th week, the mice in placebo group had $1.34 \pm 0.01 \mathrm{~mm}$ average footpad size difference whereas the untreated and glucantime group had $3.32 \pm 0.01$ and $1.71 \pm 0.01 \mathrm{~mm}$ respectively. The mice receiving water and chloroform extract of $C$. calolepis had $1.82 \pm 0.02$ and $1.79 \pm 0.01 \mathrm{~mm}$ average footpad size respectively. The average footpad sizes observed for the mice treated with E. thorifolium water and methanol extracts were $1.79 \pm 0.01 \mathrm{~mm}$ and $1.76 \pm 0.01 \mathrm{~mm}$ respectively. It is evident from the results that the water and chloroform extracts of C. calolepis and water and methanol extracts of $E$. thorifolium exhibited in vivo activity against $L$. tropica infected mice whereas the rest of studied plant extracts were found to have insignificant activity as compared to untreated group ( $p>0.05)$. Amastigotes (Figure 2) and promastigotes (Figure 3) were present in the samples taken from the lesion of mice treated with extracts of $G$. incanum, $O$. sipyleum and $P$. lycia. The parasites in the aspiration lesion samples of the group of mice treated with water extract of $E$. thorifolium and chloroform and water extract of C. calolepis were found to lose vitality on the 60th day of infection. As shown in Table 5, amastigotes were present in the smear preparations of samples taken from mice treated with methanol extract of $E$. thorifolium, whereas no promastigotes were observed in the NNN medium.

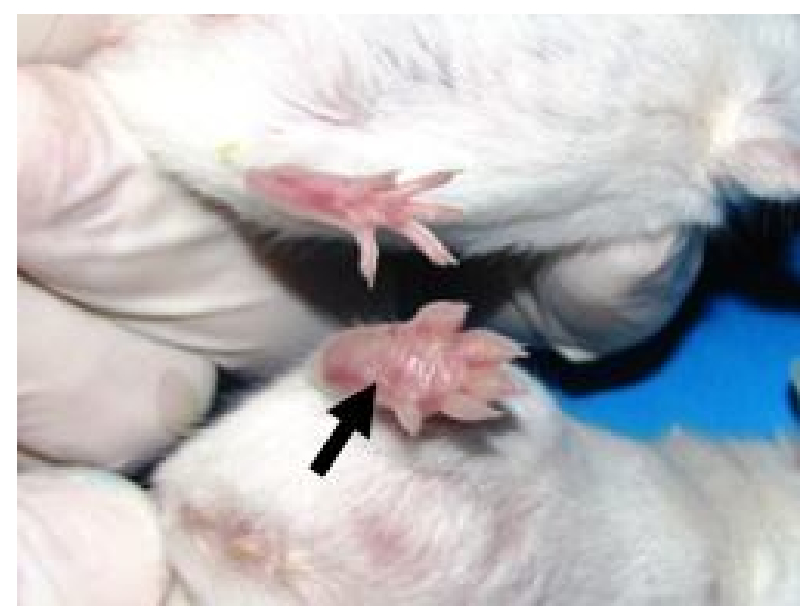

Figure 1: Cutaneous lesion on right hind mouse footpad of untreated group

Trop J Pharm Res, December 2014; 13(12): 2051 


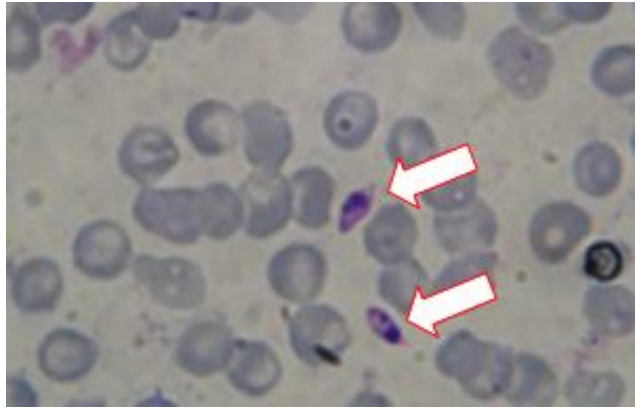

Figure 2: Amastigotes observed in neddle aspiration samples

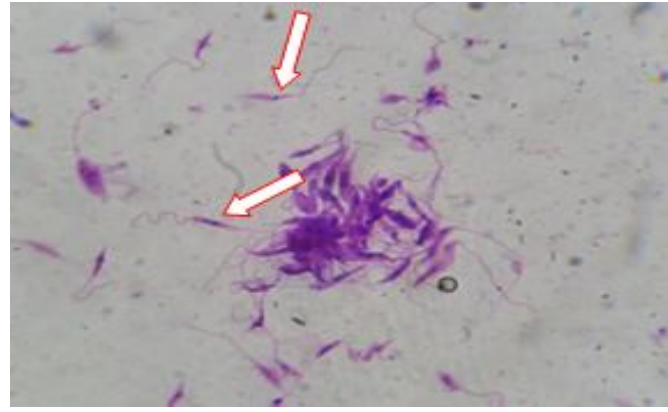

Figure 3: Promastigotes observed in NNN medium

Table 4: In vitro parasite inhibition percentages of plant extracts, glucantime and untreated groups

\begin{tabular}{|c|c|c|c|c|c|c|}
\hline \multirow{2}{*}{ Plant extract } & \multirow{2}{*}{$\begin{array}{l}\text { Time } \\
\text { (h) }\end{array}$} & \multicolumn{5}{|c|}{ Parasite inhibition \pm SD (\%)* } \\
\hline & & $25 \mu g / m L$ & $50 \mu g / m L$ & $125 \mu g / m L$ & $250 \mu g / m L$ & $500 \mu \mathrm{g} / \mathrm{mL}$ \\
\hline \multicolumn{7}{|l|}{ C. calolepis } \\
\hline \multirow[t]{3}{*}{ Water } & 12 & $16.70 \pm 0.01$ & $25.00 \pm 0.01$ & $46.70 \pm 0.02$ & $84.20 \pm 0.04$ & $99.20 \pm 0.04$ \\
\hline & 24 & $14.30 \pm 0.03$ & $35.70 \pm 0.01$ & $62.90 \pm 0.04$ & $93.60 \pm 0.03$ & $99.40 \pm 0.04$ \\
\hline & $48-72$ & $12.50 \pm 0.01$ & $56.30 \pm 0.01$ & $83.80 \pm 0.03$ & $97.50 \pm 0.02$ & $99.70 \pm 0.04$ \\
\hline \multirow[t]{3}{*}{ Chloroform } & 12 & $98.60 \pm 0.02$ & $100.0 \pm 0.00$ & $100.0 \pm 0.00$ & $100.0 \pm 0.00$ & $100.0 \pm 0.00$ \\
\hline & 24 & $100.0 \pm 0.00$ & $100.0 \pm 0.00$ & $100.0 \pm 0.00$ & $100.0 \pm 0.00$ & $100.0 \pm 0.00$ \\
\hline & $48-72$ & $99.50 \pm 0.01$ & $100.0 \pm 0.00$ & $100.0 \pm 0.00$ & $100.0 \pm 0.00$ & $100.0 \pm 0.00$ \\
\hline \multicolumn{7}{|l|}{ P. lycia } \\
\hline \multirow[t]{3}{*}{ Water } & 12 & $16.70 \pm 0.01$ & $25.00 \pm 0.04$ & $40.00 \pm 0.04$ & $71.70 \pm 0.03$ & $98.40 \pm 0.02$ \\
\hline & 24 & $42.90 \pm 0.02$ & $48.60 \pm 0.03$ & $52.90 \pm 0.01$ & $78.60 \pm 0.01$ & $99.30 \pm 0.01$ \\
\hline & $48-72$ & $12.50 \pm 0.02$ & $43.80 \pm 0.04$ & $65.00 \pm 0.02$ & $83.80 \pm 0.01$ & $99.50 \pm 0.01$ \\
\hline \multirow{3}{*}{ Chloroform } & 12 & $65.00 \pm 0.06$ & $78.30 \pm 0.04$ & $92.50 \pm 0.01$ & $96.70 \pm 0.02$ & $97.70 \pm 0.01$ \\
\hline & 24 & $78.60 \pm 0.02$ & $93.60 \pm 0.04$ & $97.10 \pm 0.02$ & $98.00 \pm 0.01$ & $98.70 \pm 0.02$ \\
\hline & $48-72$ & $99.40 \pm 0.01$ & $97.50 \pm 0.02$ & $98.30 \pm 0.002$ & $98.90 \pm 0.01$ & $99.40 \pm 0.02$ \\
\hline \multicolumn{7}{|c|}{$\begin{array}{l}\text { Galium incanum } \\
\text { ssp. centrale }\end{array}$} \\
\hline \multirow[t]{3}{*}{ Water } & $12^{* *}$ & $16.70 \pm 0.01$ & $25.00 \pm 0.05$ & $41.70 \pm 0.04$ & $45.00 \pm 0.04$ & $61.70 \pm 0.08$ \\
\hline & 24 & $28.60 \pm 0.04$ & $35.70 \pm 0.04$ & $50.00 \pm 0.06$ & $64.30 \pm 0.03$ & $82.90 \pm 0.04$ \\
\hline & $48-72$ & $12.50 \pm 0.07$ & $25.00 \pm 0.03$ & $68.80 \pm 0.06$ & $85.00 \pm 0.04$ & $95.00 \pm 0.08$ \\
\hline \multirow[t]{3}{*}{ Chloroform } & 12 & $45.00 \pm 0.04$ & $53.30 \pm 0.06$ & $75.00 \pm 0.02$ & $85.00 \pm 0.02$ & $95.20 \pm 0.06$ \\
\hline & 24 & $54.30 \pm 0.04$ & $65.70 \pm 0.04$ & $81.40 \pm 0.02$ & $95.00 \pm 0.04$ & $98.60 \pm 0.04$ \\
\hline & $48-72$ & $71.30 \pm 0.01$ & $85.00 \pm 0.02$ & $96.90 \pm 0.01$ & $99.00 \pm 0.04$ & $99.70 \pm 0.03$ \\
\hline \multicolumn{7}{|l|}{ E. thorifolium } \\
\hline \multirow[t]{3}{*}{ Water } & 12 & $25.00 \pm 0.01$ & $41.70 \pm 0.04$ & $51.70 \pm 0.02$ & $78.30 \pm 0.04$ & $97.40 \pm 0.02$ \\
\hline & 24 & $50.00 \pm 0.04$ & $60.00 \pm 0.03$ & $82.90 \pm 0.12$ & $97.60 \pm 0.03$ & $99.20 \pm 0.04$ \\
\hline & $48-72$ & $80.00 \pm 0.04$ & $87.50 \pm 0.04$ & $99.20 \pm 0.05$ & $99.40 \pm 0.04$ & $99.60 \pm 0.02$ \\
\hline \multirow[t]{3}{*}{ Methanol } & 12 & $100.0 \pm 0.00$ & $100.0 \pm 0.00$ & $100.0 \pm 0.00$ & $100.0 \pm 0.00$ & $100.0 \pm 0.00$ \\
\hline & 24 & $100.0 \pm 0.00$ & $100.0 \pm 0.00$ & $100.0 \pm 0.00$ & $100.0 \pm 0.00$ & $100.0 \pm 0.00$ \\
\hline & $48-72$ & $100.0 \pm 0.00$ & $100.0 \pm 0.00$ & $100.0 \pm 0.00$ & $100.0 \pm 0.00$ & $100.0 \pm 0.00$ \\
\hline \multicolumn{7}{|l|}{ O. sipyleum } \\
\hline \multirow[t]{3}{*}{ Water } & 12 & $16.70 \pm 0.02$ & $25.00 \pm 0.02$ & $38.30 \pm 0.04$ & $73.30 \pm 0.02$ & $97.50 \pm 0.04$ \\
\hline & 24 & $14.30 \pm 0.04$ & $28.60 \pm 0.02$ & $52.90 \pm 0.04$ & $81.40 \pm 0.01$ & $98.40 \pm 0.02$ \\
\hline & $48-72$ & $12.50 \pm 0.01$ & $25.00 \pm 0.01$ & $61.30 \pm 0.03$ & $85.00 \pm 0.04$ & $98.80 \pm 0.02$ \\
\hline \multirow[t]{3}{*}{ Methanol } & $12^{* *}$ & $16.70 \pm 0.04$ & $33.30 \pm 0.04$ & $50.00 \pm 0.04$ & $58.30 \pm 0.04$ & $75.00 \pm 0.02$ \\
\hline & 24 & $28.60 \pm 0.02$ & $50.00 \pm 0.01$ & $58.60 \pm 0.06$ & $75.70 \pm 0.01$ & $87.10 \pm 0.02$ \\
\hline & $48-72$ & $12.50 \pm 0.01$ & $37.50 \pm 0.03$ & $68.80 \pm 0.02$ & $83.80 \pm 0.04$ & $98.10 \pm 0.03$ \\
\hline \multicolumn{7}{|l|}{ Untreated } \\
\hline & 12 & $0.00 \pm 0.00$ & $0.00 \pm 0.00$ & $0.00 \pm 0.00$ & $0.00 \pm 0.00$ & $0.00 \pm 0.00$ \\
\hline & 24 & $0.00 \pm 0.00$ & $0.00 \pm 0.00$ & $0.00 \pm 0.00$ & $0.00 \pm 0.00$ & $0.00 \pm 0.00$ \\
\hline & $48-72$ & $0.00 \pm 0.00$ & $0.00 \pm 0.00$ & $0.00 \pm 0.00$ & $0.00 \pm 0.00$ & $0.00 \pm 0.00$ \\
\hline \multicolumn{7}{|l|}{ Glucantime } \\
\hline & 12 & $100.0 \pm 0.00$ & $100.0 \pm 0.00$ & $100.0 \pm 0.00$ & $100.0 \pm 0.00$ & $100.0 \pm 0.00$ \\
\hline & 24 & $100.0 \pm 0.00$ & $100.0 \pm 0.00$ & $100.0 \pm 0.00$ & $100.0 \pm 0.00$ & $100.0 \pm 0.00$ \\
\hline & $48-72$ & $100.0 \pm 0.00$ & $100.0 \pm 0.00$ & $100.0 \pm 0.00$ & $100.0 \pm 0.00$ & $100.0 \pm 0.00$ \\
\hline
\end{tabular}

${ }^{\star}$ Results are expressed as mean $\pm S D(p<0.05) ;{ }^{\star *}$ No significant difference compared to untreated group $(p>0.05)$ 


\section{DISCUSSION}

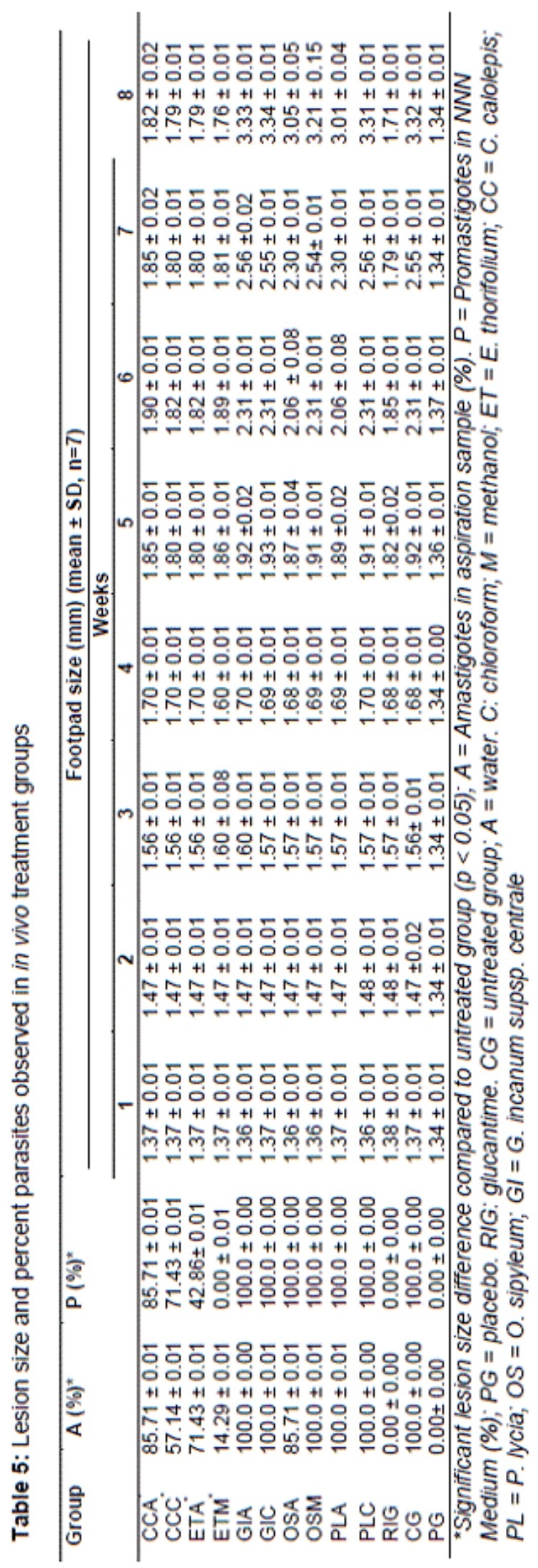

In recent years, plant-derived products are gaining increasing scientific attention in the ongoing search for better leishmanicidal compounds [27]. Some researchers looking for new alternatives for the treatment of leishmaniasis have focused on microorganisms and plants [28]. Faramea guainensis was reported to have significant in vivo leishmanicidal activity on Leishmania amazoensis [29]. In India, $L$. donovani- infected mice were successfully treated with ethanolic extracts of Alstonia scholaris and Swertia chirata at a dose of 1 $\mathrm{g} / \mathrm{kg} /$ day [30]. In a study conducted in Spain on antileishmanial activities of 12 plant species, Inula montana, Bupleurum rigidum and Scrophularia scorodonia were found to have promising potential [31]. In another study in Colombia, Annona muricata showed higher antileishmanial activity on $L$. brazielensis and $L$. paramensis than the reference drug, glucantime [32]. However, there are few studies in literature reporting the activity of plant extracts and plant derived compounds against $L$. tropica parasites. In a previous work on Haplophyllum myrtifolium, the extracts and pure compounds were reported to have both in vivo and in vitro activity on $L$. tropica [6]. The ethanol, water and n-hexane extracts from the leaves of Arbutus unedo were tested in vitro against $L$. tropica promastigotes and the ethanol extract of $A$. unedo leaves at the concentrations of $100,250,500 \mu \mathrm{g} / \mathrm{ml}$ were found to be more effective than the other extracts [33]. Extracts of the fruits of $M$. azedarach and $N$. oleander brought about 97 and $81.5 \%$ inhibition of $L$. tropica promastigotes respectively [34]. In this study, selected Turkish medicinal plants from Eryngium, Origanum, Centurea, Phlomis and Galium genus were evaluated against $L$. tropica. In a previous investigation, Fokialakis et al reported that the dichlormethane extracts of Eryngium ternatum, Origanum dictamnus and Origanum microphyllum and methanol extract of Eryngium amorginum had significant in vitro anti-leishmanial activity against L. donovani [13]. Antiprotozoal and antimicrobial activities of Centaureae species growing in Turkey were investigated in vitro and the highest anti-leishmanial activities among the extracts were observed with the chloroform extract of $C$. hierapolitana [16].

A fraction obtained from the $n$-hexane extract of Galium mexicanum inhibited the growth of $L$. donovani parasite at a concentration of 333 $\mu \mathrm{g} / \mathrm{ml}$ for the period of 72 hours [35]. The chloroform, n-hexane and water extracts of Phlomis curdica and Phlomis leucophracta were 
reported to possess inhibitory activity against $L$. donovani amastigotes [21]. Thus, the present study constitutes the first report on antileishmanial activities of plant extracts of Centaurea calolepis, Phlomis lycia, Eryngium thorifolium, Origanum sipyleum and Galium incanum ssp. centrale.

The polarity and the nature of phytochemical compounds present in plant materials are the main factors that must be considered for selection of extraction solvent. The type of extractant may range from non-polar to polar solvent depending on the targeted bioactive components. In the present work, the sample preparation disparity in regarding the choice of solvent was based on the extraction yield and on our previous preliminary antiprotozoal investigations on the plant species. Water and chloroform extracts of C. calolepis, G. incanum ssp. centrale and $P$. lycia and the water and methanol extracts of $E$. thorifolium and $O$. sipyleum were comparatively investigated. In vitro studies have shown that all the investigated extracts exhibited 98.1-100\% inhibitory effect on L. tropica promastigotes at the highest dose of $500 \mu \mathrm{g} / \mathrm{ml}$. Secondary metabolites such as alkaloids, flavonoids, saponins and terpenoids were known to possess antileishmanial activities $[4,36]$. Thus the inhibitory effect of the extracts could be due to presence of wide range of secondary metabolites with different polarities.

In the present study, the extracts of Eryngium thorifolium and Centaureae calolepis had both in vitro and in vivo effects on $L$. tropica. After the 60th day of infection, live promastigotes were not detected in the groups of mice treated with $E$. thorifolium methanol extract. This activity was explained by the mechanism of extract either by killing parasites or causing metabolic disorders to inhibit the reproduction of parasites.

To the best of our knowledge, this is the first study of the cytotoxic effect as well as the in vivo and in vitro antileishmanial activities of these plants.

\section{CONCLUSION}

Both the in vivo and in vitro results and parasite viability findings confirm that $E$. thorifolium methanol extract, which possesses terpenoids, flavonoids, anthracenes and tannins, is a potential source of new and selective antileishmanial agents.

\section{ACKNOWLEDGEMENT}

This study received financial support from TUBITAK (The Scientific and Technological Research Council of Turkey) - grant no. $110 S 289$.

\section{REFERENCES}

1. World Health Organisation, Control of the leishmaniasis: Report of a meeting of the WHO Expert Committee on the Control of Leishmaniases, Geneva, WHO Technical Report Series 949, 2010; pp 1-12.

2. Mishra BB, Kale RR, Prasad V, Tiwari VK and Singh RK. Scope of natural products in fighting against leishmaniasis. In: Bioactive natural products: Opportunities and Challenges in Medicinal Chemistry, 1st ed. World Scientific Publishing Company; 2011; pp 121-154.

3. Sawadogo WR, Le Douaron G, Maciuk A, Bories C, Loiseau PM, Figadere B, Guissou IP, Nacoulma OG. In vitro antileishmanial and antitrypanosomal activities of plants from Burkina Faso. Parasitol Res 2012; 110: 1779-1783.

4. Chan-Bacab MJ, Pena-Rodriguez LM. Plant natural products with leishmanicidal activity. Nat Prod Rep 2001; 18: 674-688.

5. Gonzales-Coloma A, Reina M, Saenz C, Lacret R, RuizMesia L, Aran VJ, Sanz J, Martinez-Diaz RA. Antileishmanial, antitrypanosomal and cytotoxic screening of ethnopharmacologically selected Peruvian plants. Parasitol Res 2012; 110: 1381-1392

6. Ostan I, Saglam H, Limoncu ME, Ertabaklar H, Ozensoy Toz S, Ozbel Y, Ozbilgin A. In vitro and in vivo activities of Haplophyllum myrtifolium against Leishmania tropica. New Microbiologica 2007; 30: 439-444.

7. Ozbilgin A, Durmuskahya $C$, Kilimcioglu AA, Kayalar $H$, Kurt O., Ermiş $V$, et al. In vitro efficacy of Quercus infectoria Oliv. and Achillea millefolium L. Extracts against Blastocystis spp. Isolates. Kafkas Univ Vet Fak Derg 2013; 19: 511-516.

8. Ozbilgin A, Durmuskahya $C$, Kayalar $H$, Ostan I. Assesment of in vivo antimalarial activities of some selected medicinal plants from Turkey. Parasitol Res 2014; 113: 165-173.

9. Trease GE, Evans WC. Trease and Evans Pharmacognosy: A Physicians's Guide to Herbal Medicine. 15th edn. W.B. Saunders, 2002.

10. Harborne JB. Phtochemical Methods, A guide to modern techniques of plant analysis. 3rd ed. Chapman and Hall, New York, 1998, p. 1-150.

11. Sarker SD, Laird A, Nahar L, Kumarasamy Y, Jaspars M. Indole alkaloids from the seeds of Centaurea cyanus (Asteraceae). Phytochemistry 2001; 57: 1273-1276.

12. Karamenderes $C$, Khan S, Tekwani BL. Antiprotozoal and antimicrobial activites of Centaurea species growing in Turkey. Pharm Biol 2006; 44: 534-539.

Trop J Pharm Res, December 2014; 13(12): 2054 
13. Fokialakis N, Kalpoutzakis E, Tekwani BL. Evaluation of the antimalarial and antileishmanial activity of plants from the Greek island of Crete. J Nat Med 2007; 61: 38-45.

14. Kartnig T, Wolf J. Flavonoids from the aerial parts of Eryngium campestre. Planta Med 1993; 59: 285-285.

15. Taleb-Contini SH, Salvador MJ, Balanco JMF, Albuquerque $S$, de Oliveira DC. Antiprotozoal effect of crude extracts and flavonoids isolated from Chromolaena hirsuta (Asteraceae). Phytother Res 2004; 18: 250-254.

16. Aligiannis N, Kalpoutzakis E, Mitaku S, Chinou I. Composition and antimicrobial activity of the essential oils of two Origanum species. J Agric Food Chem 2001; 49: 4168-4170

17. Torres-Santos EC, Lopes $D$, Oliveira RR, Carauta JP, Falcao CA, Kaplan MA, et al. Antileishmanial activity of isolated triterpenoids from Pourouma guianensis. Phytomedicine 2004; 11: 114-120.

18. Calis I, Heilmann J, Tasdemir D. Flavonoid, iridoid and lignan glycosides from Putoria calabrica. J Nat Prod 2001; 66: 961-964.

19. Calis I, Tasdemir D, Ireland CM, Sticher O. Lucidin type anthraquinone glycosides from Putoria calabrica. Chem Pharm Bull 2002; 50: 701-702.

20. Katagiri M, Ohtani K, Kasai R, Yamasaki K, Yang CR, Tanaka O. Diterpenoid glycosyl esters from Phlomis younghusbandii and $P$. medicinalis roots. Phytochemistry 1994; 35: 439-442.

21. Tasdemir D, Brun R, Perozzo R, Donmez AA. Evaluation of antiprotozoal and plasmodial Enoly-ACP reductase inhibition potential of Turkish medical plants. Phytotherapy Research 2005; 19: 162-166.

22. Kartnig $T$, Wolf $J$. Flavonoids from the aerial parts of Eryngium campestre. Planta Med 1993; 59: 285-285.

23. Allahverdiyev $A M$, Uzun $S$, Bagirova $M$, Durdu $M$, Memisoglu HR. A sensitive new microculture method for diagnosis of cutaneous leishmaniasis. Am J Trop Med Hyg 2004; 70: 294-297.

24. Zhai L, Chen M, Blom J, Theander TG, Kharazmi A. The antileishmanial activity of novel oxygenated chalcones and their mechanism of action. J Antimic Chemother 1999; 43: 793-803.

25. Napolitiano HB, Silva M, Ellena J, Rodriques BDG. Aurapten, a coumarin with growth inhibition against
Leishmania major promastigotes. Brazilian J Med Biol Res 2004; 37: 1847-1852.

26. Navarro MC, Montilla MP, Cabo MM, Galisteo M. Antibacterial, antiprotozoal and antioxidant activity of five plants used in Izabal for infectious diseases. Phytother Res 2003; 17: 325-329.

27. Butler MS. Natural products to drugs: natural product derived compounds in clinical trials. Nat Prod Rep 2005; 22: 162-195.

28. Santos DO, Coutinho CE, Madeira MF, Bottino CG, Vieira RT, Nascimento SB, et al. Leishmaniasis treatment-a challenge that remains: a review. Parasitol Res 2008; 103: 1-10.

29. Sauvain M, Dedet JP, Kunesch N, Poisson J. Isolation of flavans from the amazonian shrub Faramea guianensis. J Nat Prod 1994; 57: 403-406.

30. Singha UK, Guru PY, Sen AB, Tandon JS. Antileishmanial activity of traditional plants against Leishmania donovani in golden hamsters. Int $\mathrm{J}$ Pharmacog 1992; 30: 289-295

31. Martin T, Villaescusa L, Gasquet M. Screening for protozoocidal activity of Spanish 88 plants. Pharm Biol 1998; 36: 56-62.

32. Jaramillo MC, Arango GJ, Gonzalez MC, Robledo SM, Velez ID. Cytotoxicity and antileishmanial activity of Annona muricata pericarp. Fitoterapia 2000; 71: 183186.

33. Kivcak B, Mert T, Ertabaklar H, Balcioglu C, Ozensoy Toz S. In vitro activity of Arbutus unedo against Leishmania tropica promastigotes. Turk J Parasitology 2009; 33: 114-115.

34. Al-Jubouri SA, Al-Khan HI. Effect of aqueous extracts of Nerium oleander and Melia azederach on growth Leishmania tropica promastigotes in vitro. Tikrit $J$ Pure Science 2009; 14: 42-45.

35. Bolivar P, Cruz-Paredes C, Hernandez LR, Juarez ZN, Sanches-Arreola E, Av-Gay Y, Bach H. Antimicrobial, anti-inflammatory, antiparasitic and cytotoxic activities of Galium mexicanum. J Ethopharmacol. 2011; 137: 141-147.

36. Salehabadi A, Karamian M, Farzad M H, Namaei MH. Effect of root bark extract of Berberis vulgaris $L$. on Leishmania major on Balb/c mice. Parasitol Res 2014; 113: 953-957. 